Original Research Article

\title{
Drug utilization review of general anaesthetic agents in a tertiary care hospital
}

\author{
G. Gomathi' ${ }^{1}$ Ghanshyam $\operatorname{Yadav}^{2}$, B. L. Pandey ${ }^{1 *}$
}

\author{
${ }^{1}$ Department of Pharmacology, \\ ${ }^{2}$ Department of \\ Anaesthesiology, Institute of \\ Medical Sciences, Banaras \\ Hindu University, Varanasi, \\ Uttar Pradesh, India
}

Received: 07 December 2017

Accepted: 28 December 2017

*Correspondence to:

Dr. B. L. Pandey,

Email: blp53@rediffmail.com

Copyright: (C) the author(s), publisher and licensee Medip Academy. This is an openaccess article distributed under the terms of the Creative Commons Attribution NonCommercial License, which permits unrestricted noncommercial use, distribution, and reproduction in any medium, provided the original work is properly cited.

\begin{abstract}
Background: Drug utilization review plays a key role in helping the healthcare system to understand, interpret and improve the prescribing, administration and use of medications. The principle aim of drug utilization review was to facilitate rational use of drugs, which implies the prescription of a well documented drug in an optimal dose on the right indication.

Methods: An observational study of anaesthetic practice was carried out in the department of Anaesthesiology in tertiary care hospital, Varanasi after approval from institutional ethical committee. The data of patients who underwent surgery under general anaesthesia were collected in predesigned patient profile form and were analyzed for drug utilization review.

Results: 110 patients were enrolled with mean age $35.30 \pm 17.99$ years and mean weight $51.32 \pm 15.32 \mathrm{~kg}$. Laparoscopic cholecystectomy (43.63\%), otorhinolaryngology surgeries $(36.36 \%)$, cardiothoracic vascular surgery $(4.54 \%)$, neurosurgery $(4.54 \%)$ and other surgeries $(10.93 \%)$ required general anaesthetic agents were reviewed. Propofol $(93.63 \%)$ and etomidate $(6.36 \%)$ were used for induction of anaesthesia. Propofol (45.45\%), isoflurane (53.63\%), sevoflurane $(0.90 \%)$ were administered for maintenance of anaesthesia in various surgeries. Adverse outcomes observed were hypotension $(7.27 \%)$, bradycardia $(6.36 \%)$, hypertension $(3.63 \%)$ and post operative nausea and vomiting (PONV) $(2.72 \%)$.

Conclusions: Propofol is most commonly prescribed drug for induction of anaesthesia. Isoflurane is most commonly prescribed inhalational anaesthetic agent for maintenance of anaesthesia followed by Propofol. Hypotension is most common adverse outcome observed.
\end{abstract}

Keywords: General anaesthesia, Practice, Utilization review

\section{INTRODUCTION}

Drug utilization review is an ongoing, systematic process designed to maintain the appropriate and effective use of medications. ${ }^{1}$ Drug utilization review play a key role in helping managed health care systems to understand, interpret and improve the prescribing, administration and use of medications.

It involves a comprehensive review of a patient's medication and health history before, during, and after dispensing in order to attempt to achieve appropriate therapeutic decision making and positive patient outcomes. Drug utilization review ensures whether the drugs are used appropriately, safely and effectively to improve patient health status

General anaesthesia was chosen as a topic for drug utilization study because general anaesthetics are major and important drug category in use, in which the practice has to be taken into consideration of several aspects of convenience and safety. This study is an attempt to evaluate the choice or decision of particular general anaesthetic agent, the process of use, which includes defined rules of administration and monitoring of unfavourable outcomes. 


\section{METHODS}

The present observational study was conducted in collaboration of the Department of Pharmacology and Department of Anaesthesiology and associated Sir Sunder Lal Hospital (SSLH), Banaras Hindu University and Trauma centre, Varanasi. The study spanned over a period ranging from November 2015 - February 2017.

All the patients planned to undergo surgery barring obstetric and gynaecological procedures under general anaesthesia were enrolled in the study. The patient's informed consent was obtained for using their details and clinical data with assurance of not revealing personal identity without their concurrence. This study was duly approved by Institute Ethical Committee (IEC).

A predesigned proforma was used to collect data on decision for choice of particular anaesthetic agent for particular surgery, process of administration and monitoring of drug and adverse outcomes if any was noted down under the guidance of anaesthetist.

\section{Statistical analysis}

Descriptive analysis was used to analyse the data. SPSS version 19 was used for analysis of data. Qualitative variables were expressed as a percentage.

\section{RESULTS}

110 cases underwent surgery under general anaesthesia were covered comprising 68 males and 42 females in the study with mean age of $35.30 \pm 17.99$ and mean weight $51.32 \pm 15.32$ (Table 1).

Table 1: Patient's baseline characteristics.

\begin{tabular}{|llll|}
\hline Parameters & $\begin{array}{l}\text { Mean } \pm \text { SD } \\
(\mathbf{N}=110)\end{array}$ & Median & Range \\
\hline Age (years) & $35.30 \pm 17.99$ & 35 & $2-65$ \\
\hline Weight $(\mathrm{kg})$ & $51.32 \pm 15.32$ & 54.5 & $7-76$ \\
\hline Height $(\mathrm{cm})$ & $152.96 \pm 15.32$ & 155.5 & $85-175$ \\
\hline BMI $\left(\mathrm{kg} / \mathrm{m}^{2}\right)$ & $21.30 \pm 4.61$ & 21.5 & $11.83-30.4$ \\
\hline $\begin{array}{l}\text { Systolic BP } \\
(\mathrm{mm} \mathrm{Hg})\end{array}$ & $117.03 \pm 16.5$ & 115 & $90-150$ \\
\hline $\begin{array}{l}\text { Diastolic BP } \\
(\mathrm{mm} \mathrm{Hg})\end{array}$ & $73.05 \pm 9.74$ & 70 & $60-90$ \\
\hline
\end{tabular}

\section{Preanaesthetic medications}

Among preanaesthetic medications tab. ranitidine (75$150 \mathrm{mg})$ and tab. alprazolam $(0.25-0.5 \mathrm{mg})$ were administered two hours before surgery to all patients as an antacid and anxiolytic medication respectively. Inj. midazolam (0.5-1 mg) was administered in majority of the patients $(96 \%)$ before induction as anxiolytic medication. Inj. ondansetron $(0.1 \mathrm{mg} / \mathrm{kg})$, an antiemetic medication was administered to all patients intraoperatively. Opioid analgesic, inj. fentanyl $(1-2 \mathrm{mcg} / \mathrm{kg})$ was administered before induction and repeated intraoperatively in procedures of long duration (Table 3).

Table 2: Procedures incorporated in the study.

\begin{tabular}{|lll|}
\hline Procedures & $\begin{array}{l}\text { Frequency } \\
\text { (n) }\end{array}$ & $\begin{array}{l}\text { Percent } \\
(\%)\end{array}$ \\
\hline $\begin{array}{l}\text { Laparoscopic } \\
\text { cholecystectomy }\end{array}$ & 48 & 43.63 \\
\hline $\begin{array}{l}\text { Otorhinolaryngiological } \\
\text { surgery }\end{array}$ & 40 & 36.36 \\
\hline $\begin{array}{l}\text { Modified radical } \\
\text { mastectomy }\end{array}$ & 6 & 5.45 \\
\hline Cardio vascular surgery & 5 & 4.54 \\
\hline Neurosurgery & 5 & 4.54 \\
\hline Other procedures & 6 & 5.45 \\
\hline
\end{tabular}

Table 3: Preanaesthetic medications.

\begin{tabular}{|c|c|c|}
\hline Drug & $\begin{array}{l}\text { Dose } \\
(\text { Mean } \pm \text { SD })\end{array}$ & Range \\
\hline Tab. Ranitidine (mg) & $139.31 \pm 7.15$ & $75-150$ \\
\hline $\begin{array}{l}\text { Tab. Alprazolam } \\
(\mathrm{mg})\end{array}$ & $0.48 \pm 0.06$ & $0.25-0.5$ \\
\hline Inj. Midazolam (mg) & $1.14 \pm 0.4$ & $\begin{array}{l}0.5-1(0.01- \\
0.05 \mathrm{mg} / \mathrm{kg})\end{array}$ \\
\hline $\begin{array}{l}\text { Inj. Ondansetron } \\
(\mathrm{mg})\end{array}$ & $3.92 \pm 0.46$ & $\begin{array}{l}2-8 \\
(0.1 \mathrm{mg} / \mathrm{kg})\end{array}$ \\
\hline Inj. Fentanyl (mcg) & $139.68 \pm 101.13$ & $1-2 \mathrm{mcg} / \mathrm{kg}$ \\
\hline
\end{tabular}

Inj. propofol $(1.5-2.5 \mathrm{mg} / \mathrm{kg})$ was most commonly administered for induction of anaesthesia which was about $93.6 \%$ followed by Inj. etomidate $(0.2-0.6 \mathrm{mg} / \mathrm{kg})$ which was about $6.4 \%$ (Figure 1).

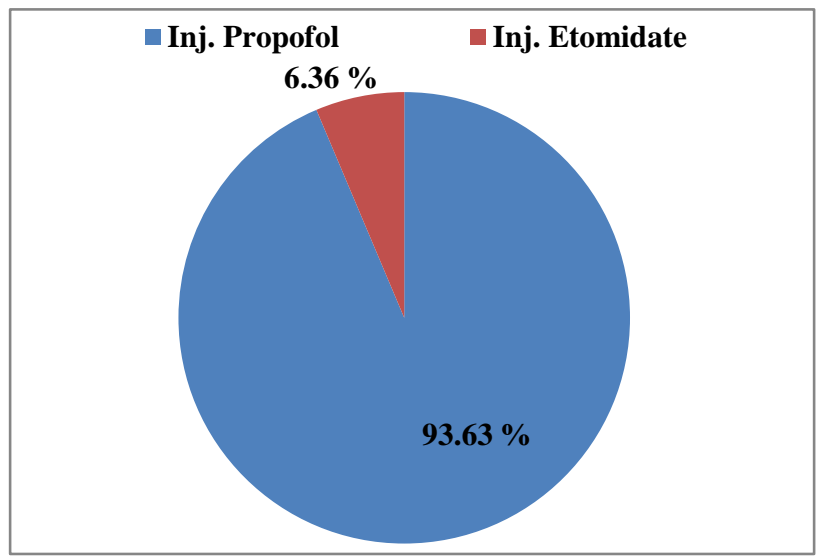

Figure 1: Induction of anaesthesia.

Among inhalational anaesthetic agents, isoflurane with nitrous oxide was most commonly used for maintenance of anaesthesia followed by total intravenous infusion of propofol at an infusion rate of $75-125 \mathrm{mcg} / \mathrm{kg} / \mathrm{min}$ (Figure 2). 


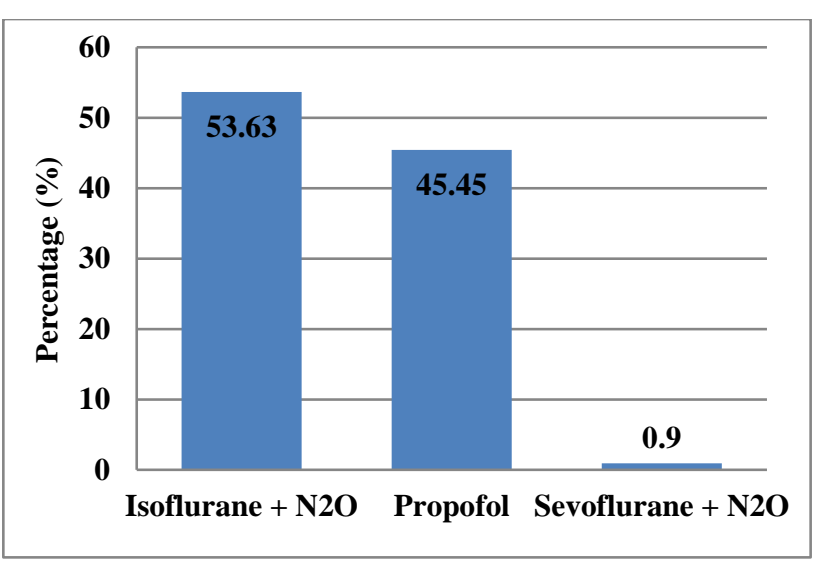

Figure 2: Maintenance of anaesthesia.

In Table 4, anaesthetic agents administered for abdominal surgeries are presented. Inj.propofol is universal choice for induction of anaesthesia in abdominal surgeries of short and long duration. Inj.propofol was used as inducing agent in all patients who underwent laparoscopic cholecystectomy except one patient where inj. etomidate was used. Inj.etomidate was preferred agent for induction of anaesthesia in patients with cardiovascular instability.
Inj. propofol was used as an inducing agent in exploratory laparotomy and jejunostomy reversal.

Total intravenous infusion of propofol was preferred for maintenance of anaesthesia in laparoscopic cholecystectomy which was surgery of short duration. Isoflurane was used for maintenance of anaesthesia in laparoscopic cholecystectomy cases which were anticipated that the duration of surgery will be prolonged.

In Table 5, anaesthetic agents administered for otorhinolaryngological procedures are presented. It was routine practice to administer inj.propofol for induction and isoflurane with nitrous oxide and oxygen for maintenance of anaesthesia considering the fact that the duration of these procedures was more than 30 minutes to 2 hours.

In Table 6, anaesthetic agents administered for neurosurgery cases are presented. Inj.propofol was used for induction and total intravenous infusion of propofol was used for maintenance of anaesthesia. Even though the duration of neurosurgical procedures were more than 2 hours, propofol was preferred in the study population.

Table 4: Anaesthetic agents administered for abdominal surgeries.

\begin{tabular}{|llllll|}
\hline \multirow{2}{*}{ Procedure } & \multicolumn{4}{l|}{ Induction of anaesthesia N (\%) } & \multicolumn{3}{l|}{ Maintenance of anaesthesia N $(\%)$} \\
\hline Laparoscopic Cholecystectomy & Propofol & Etomidate & Propofol & Isoflurane & Sevoflurane \\
\hline Exploratory Laparotomy & 2 & $1(2)$ & $45(94)$ & $2(4)$ & $1(2)$ \\
\hline Jejunostomy Reversal & 1 & 0 & 0 & 2 & 0 \\
\hline
\end{tabular}

Table 5: Anaesthetic agents administered for Otorhinolaryngiological surgeries.

\begin{tabular}{|c|c|c|c|c|c|}
\hline \multirow{2}{*}{ Procedure } & \multicolumn{2}{|c|}{ Induction of anaesthesia (N) } & \multicolumn{3}{|c|}{ Maintenance of anaesthesia (N) } \\
\hline & Propofol & Etomidate & Propofol & Isoflurane $+\mathrm{N}_{2} \mathrm{O}$ & Sevoflurane $+\mathrm{N}_{2} \mathrm{O}$ \\
\hline $\begin{array}{l}\text { Functional Endoscopic } \\
\text { Sinus Surgery (FESS) }\end{array}$ & 20 & 0 & 0 & 20 & 0 \\
\hline Adenotonsillectomy & 8 & 0 & 0 & 8 & 0 \\
\hline Mid Facial degloving & 3 & 0 & 0 & 3 & 0 \\
\hline Sinus tract excision & 2 & 0 & 0 & 2 & 0 \\
\hline $\begin{array}{l}\text { Lengthening temporalis } \\
\text { myoplasty }\end{array}$ & 2 & 0 & 0 & 2 & 0 \\
\hline $\begin{array}{l}\text { Temporomandibular } \\
\text { osteotomy }\end{array}$ & 2 & 0 & 0 & 2 & 0 \\
\hline Polypectomy & 1 & 0 & 0 & 1 & 0 \\
\hline Total thyroidectomy & 1 & 0 & 0 & 1 & 0 \\
\hline Biopsy & 1 & 0 & 0 & 1 & 0 \\
\hline
\end{tabular}

Table 6: Anaesthetic agents administered for Neurosurgery.

\begin{tabular}{|llllll|}
\hline \multirow{2}{*}{ Procedure } & \multicolumn{2}{l}{ Induction of anaesthesia $(\mathbf{N})$} & \multicolumn{2}{l|}{ Maintenance of anaesthesia $(\mathbf{N})$} \\
\cline { 2 - 6 } & Propofol & Etomidate & Propofol & Isoflurane & Sevoflurane \\
\hline Craniotomy & 2 & 0 & 2 & 0 & 0 \\
\hline Gross tumour resection & 2 & 0 & 2 & 0 & 0 \\
\hline Ventriculoperitonial shunt & 1 & 0 & 1 & 0 & 0 \\
\hline
\end{tabular}


In Table 7, anaesthetic agents administered for cardiothoracic vascular surgeries are presented. Inj.etomidate is drug of choice for induction of anaesthesia in these cases because the effect of etomidate on cardiovascular system is minimal compared to propofol. Isoflurane with $\mathrm{N}_{2} \mathrm{O}$ was used for maintenance of anaesthesia in these patients.

In Table 8, anaesthetic agents administered for modified radical mastectomy, radical cystectomy with neobladder, transurethral resection of the prostate and percutaneous nephrolithotomy are presented. Inj. propofol is drug of choice for induction of anaesthesia except for one patient in whom intraoperative cardiovascular complications were anticipated hence Inj.etomidate is used for induction in that patient. Isoflurane with nitrous oxide and oxygen were used for maintenance of anaesthesia.

In Table 9, intra operative and post operative complications are presented. Intra operative complications such as hypotension, bradycardia and hypertension were observed in the study population. Post operative nausea and vomiting (PONV) and delayed recovery were observed post operatively.

Table 7: Anaesthetic agents administered for cardiothoracic vascular surgeries.

\begin{tabular}{|c|c|c|c|c|c|}
\hline \multirow{2}{*}{ Procedure } & \multicolumn{2}{|c|}{ Induction of anaesthesia (N) } & \multicolumn{2}{|c|}{ Maintenance of anaesthesia (N) } & \multirow[b]{2}{*}{ Sevoflurane $+\mathrm{N}_{2} \mathrm{O}$} \\
\hline & Propofol & Etomidate & Propofol & Isoflurane $+\mathrm{N}_{2} \mathrm{O}$ & \\
\hline Mitral Valve replacement & 0 & 2 & 0 & 2 & $\mathbf{0}$ \\
\hline Double valve replacement & 0 & 2 & 0 & 2 & $\mathbf{0}$ \\
\hline CABG & 0 & 1 & 0 & 1 & $\mathbf{0}$ \\
\hline
\end{tabular}

Table 8: Anaesthetic agents administered for other surgeries.

\begin{tabular}{|c|c|c|c|c|c|}
\hline \multirow{2}{*}{ Procedure } & \multicolumn{2}{|c|}{ Induction of anaesthesia (N) } & \multicolumn{2}{|c|}{ Maintenance of anaesthesia (N) } & \multirow[b]{2}{*}{ Sevoflurane $+\mathrm{N}_{2} \mathrm{O}$} \\
\hline & Propofol & Etomidate & Propofol & Isoflurane $+\mathbf{N}_{2} \mathrm{O}$ & \\
\hline $\begin{array}{l}\text { Modified radical } \\
\text { mastectomy }\end{array}$ & 6 & 0 & 0 & 6 & 0 \\
\hline $\begin{array}{l}\text { Radical cystectomy with } \\
\text { neobladder }\end{array}$ & 0 & 1 & 0 & 1 & 0 \\
\hline $\begin{array}{l}\text { Transurethral Resection of } \\
\text { the Prostate (TURP) }\end{array}$ & 1 & 0 & 0 & 1 & 0 \\
\hline $\begin{array}{l}\text { Percutaneous } \\
\text { nephrolithotomy (PCNL) }\end{array}$ & 1 & 0 & 0 & 1 & 0 \\
\hline
\end{tabular}

Table 9: Intra operative and post operative complications.

\begin{tabular}{|llllll|}
\hline \multirow{2}{*}{ Complication } & Induction of anaesthesia $(\mathbf{N})$ & \multicolumn{3}{l|}{ Maintenance of anaesthesia $(\mathbf{N})$} \\
\cline { 2 - 6 } & Propofol & Etomidate & Propofol & Isoflurane & Sevoflurane \\
\hline Hypotension(N=8) & 6 & 2 & 3 & 5 & 0 \\
\hline Bradycardia $(\mathrm{N}=7)$ & 6 & 1 & 3 & 4 & 0 \\
\hline Hypertension(N=4) & 3 & 1 & 1 & 2 & 1 \\
\hline PONV(N=3) & 2 & 1 & 0 & 2 & 1 \\
\hline Delayed recovery $(\mathrm{N}=2)$ & 2 & 0 & 1 & 1 & 0 \\
\hline
\end{tabular}

\section{DISCUSSION}

Drug application and improved use is facilitated by prudent drug utilization review. This includes rational decision of selecting particular medication for a condition with due reference to characteristics of the patients.

At the largest scale professional organisations propose guidelines for therapies. In the present study, use of various agents for general anaesthesia under one anaesthesiologist was observed. The drugs predominantly employed for induction and maintenance were noted. The preference of anaesthesiologist may be indirect reflection of best outcome with the medications in specific contexts.

An antacid was routinely prescribed prior to induction to decrease the volume of gastric acid and the $\mathrm{pH}$ and also to prevent aspiration. The most commonly prescribed antacid was tab. ranitidine. The finding of the study is in favour of meta-analysis by Clark et al, outcomes suggest that premedication with ranitidine is more effective than proton 
pump inhibitors in reducing the volume of gastric secretions and increasing gastric $\mathrm{Ph}^{2}$

In our study tab. alprazolam $0.25 \mathrm{mg}$ and $0.5 \mathrm{mg}$ were prescribed to children and adults respectively, was administered 2 hours before surgery to all patients as an anxiolytic medication followed by inj.midazolam with dose range of $0.5-1 \mathrm{mg}$ was administered to majority of the patients $(96 \%)$ before reduction. The IV midazolam was the most commonly used anxiolytic agent. ${ }^{3}$ Alprazolam as well as midazolam have an additive effect with intravenous anaesthetics (propofol, fentanyl) and could prolong the sedative effects after surgery.,5

Inj.fentanyl was the most commonly used opioid analgesic agent with dose range of $1-2 \mathrm{mcg} / \mathrm{kg}$, repeated intraoperatively especially in procedures of long duration. These findings were similar to previous studies where fentanyl was the most commonly used opioid analgesic.

Ondansetron was most commonly used antiemetic. A study shows that antiseratonins (ondansetron, granisetron, ramosetron) are more effective in prophylaxix of PONV than traditional antiemetics (metoclopramide, droperidol). ${ }^{6}$ A meta-analysis shows that ramosetron is superior to ondansetron for preventing PONV. ${ }^{7}$

PONV are common phenomenon after laparoscopic cholecystectomy, with a reported incidence from $53 \%$ to $72 \% .^{8,9}$ Because of the multifactorial etiology of PONV and its occurrence associated with anaesthetic techniques, there has been an increasing interest in using prophylactic antiemetic and anaesthesia with intravenous anaesthetic agents like propofol, with known antiemetic properties. A number of studies have shown the use of a multimodal approach incorporating both propofol and dexamethasone. ${ }^{10}$

In our study, induction of anaesthesia was done by propofol and maintenance of anesthesia with propofol infusion was well-tolerated by patients undergoing laparoscopic cholecystectomy. Other studies also found satisfactory anaesthesia, with good recovery characteristics and a low incidence of postoperative nausea and vomiting with propofol when compared to isoflurane. ${ }^{11}$

Propofol is preferred for the induction and maintenance of general anaesthesia in laparoscopic cholecystectomy (LC) due to low incidences of PONV. There is a strong evidence to suggest that intravenous anaesthesia with propofol reduces the PONV. ${ }^{12,13}$

Meta analysis have also supported that propofol is associated with a lower incidence of PONV than inhalational anaesthesia for induction alone has no preventive effect on PONV. ${ }^{14}$ Therefore, the difference between the propofol and isoflurane anaesthesia could be due to the emetogenic effect of volatile anaesthetics, rather than only the antiemetic effect of propofol. This led to the suggestion of prophylactic use of antiemtic in laparoscopic cholecystectomy. Prophylactic use of dexamethasone can reduce the occurrence of PONV. ${ }^{15}$ Propofol is associated with a lower risk of postoperative nausea and vomiting, thus providing better patient's satisfaction.

Tonsillectomy with or without adenoidectomy followed by functional endoscopic sinus surgery are now commonly performed surgical procedures in the otorhino-laryngology specialty. Volatile anaesthetic agents cause smooth muscle relaxation and decreases systemic vascular resistance. Tissue perfusion is increased due to vasodilatation and may also contribute to surgical bleeding. Initial studies have suggested that the intra-operative blood loss was reduced with propofol total intravenous anaesthesia (TIVA) compared to volatile agents. ${ }^{16-18}$ However, more recent studies do not show significant difference. ${ }^{19}$

Propofol has been shown to interact with the endocannabinoid system in the brain. This novel mechanism has been associated with the sedative, psychomimetic, and antiemetic properties of propofol, but there is accumulating evidence that the endocannabinoid system regulates the release of various neurotransmitters and may also be involved in neuroprotection. ${ }^{20}$

Etomidate is a short acting IV anaesthetic agent used for the induction of general anaesthesia. It has a rapid onset of action, a safe cardiovascular risk profile, and lack of histamine release and therefore is less likely to cause significant drop in blood pressure than other induction agents. It is an ideal induction agent for patients who are hemodynamically unstable.

Etomidate shown a favourable outcome and it was very well supported by Wu et al., in their study. ${ }^{21}$ Both propofol and etomidate had shown similarity in their respiratory depressant effect. The episodes of apnoea were transient and not associated with any falling oxygen saturation.

Variety of short and long duration surgeries under general anaesthesia have been observed for utilization of drug. There has been fundamentally consistent selection of preanaesthetic medications with the kind of indication and the kind of anaesthetic agent chosen.

Preferred inducing agent was propofol except in patients who were hemodynamically unstable. The later were administered etomidate for induction. This is consistent with the detailed discussion in above paragraph.

Similarly, propofol was also employed for maintenance of anaesthesia in short duration surgery as it is associated with rapid, smooth recovery and also not associated with post operative nausea vomiting. This was particularly relevant for abdominal surgeries. In long duration surgery inhalational anaesthetic agent isoflurane was common choice along with nitrous oxide and oxygen for the reasons elaborated by above discussion. Again in consistency with discussion for obvious neuroprotective and hemodynamic 
advantages total intravenous infusion anaesthesia with propofol was used for neurosurgery.

In consistent with scientific description, patients underwent cardiothoracic vascular surgery had induction of anaesthesia with etomidate and maintenance on isoflurane and nitrous oxide. The profile of adjunct agents used with general anaesthetic agents is also consistent with their understanding of pharmacodynamics and toxicological profile.

The intra operative and post operative complications suggests more cardiovascular complications and nausea, vomiting respectively when propofol was used for induction while etomidate was safe. As regards to maintenance of anaesthesia, propofol and isoflurane both have cardiovascular adverse effects. Nausea and vomiting was more with isoflurane. Sevoflurane did not associate with cardiovascular complications.

\section{CONCLUSION}

It is apparent from the observation that the choices of anaesthesia as well as outcome of procedures were predictable from theoretical understanding. The choices were therefore rational. The process of administration is highly vigilant in case of anaesthetics and the outcomes are reasonably good. The theoretical understanding therefore holds well in practice of general anaesthesia at our particular anaesthetist unit.

Funding: No funding sources Conflict of interest: None declared

Ethical approval: The study was approved by the Institutional Ethics Committee

\section{REFERENCES}

1. American Society of Health-System Pharmacists. ASHP Guidelines on Medication-Use Evaluation published. 1996;53:1953-5.

2. Clark K, Lam LT, Gibson S, Currow D: The effect of ranitidine versus proton pump inhibitors on gastric secretions: a meta-analysis of randomized control trials. Anaesthesia. 2009 Jun; 64(6):652-7.

3. Kain ZN, Mayes LC, Bell C, Hofstadter MB, Rimar S, Weisman S: Premedication in the United States: A Status Report. Anesth Analg. 1997;84:427-32.

4. Short TG, Chui PT. Propofol and midazolam act synergistically in combination. Br J Anaesth. 1991 Nov; 67(5):539-45.

5. Twyman RE, Rogers CJ, Macdonald RL. Differential regulation of gamma-aminobutyric acid receptor channels by diazepam and phenobarbital. Ann Neurol. 1989 Mar; 25(3):213-20.

6. Fujii Y. Prophylaxis of postoperative nausea and vomiting in patients scheduled for breast surgery. Clin. Drug Investig. 2006 Jan;26(8):427-37.

7. Mihara T, Tojo K, Uchimoto K, Morita S, Goto T. Reevaluation of the effectiveness of ramosetron for preventing postoperative nausea and vomiting: a systematic review and meta-analysis. Anesth. Analg. 2013 Aug;117(2):329-39.

8. Apfel CC, Kranke P, Katz MH, Goepfert C, Papenfuss $\mathrm{T}$, RauchS, et al. Volatile anaesthetics may be the main cause of early but not delayed postoperative vomiting: a randomized controlled trial of factorial design. $\mathrm{Br} \mathbf{J}$ Anaesth. 2002;88:659-68.

9. Joris LJ. Anaesthesia for laparoscopic surgery. In: Miller RD, ed. Anaesthesia. 5 ${ }^{\text {th }}$ Ed. Vol II. Philadelphia: Churchill Livingstone; 2000:2013.

10. Wang JJ, Ho ST, Uen YH, Lin MT, Chen KT, Huang JC, et al. Small - dose dexamethasone reduces nausea and vomiting after laparoscopic cholecystectomy: a comparison of tropisetron with saline. Anesth Analg. 2002;95:229-32.

11. Collins SJ, Robinson AL, Holland HF. A comparison between total intravenous anaesthesia using a propofol/alfentanil mixture and an inhalational technique for laparoscopic gynaecological sterilization. Eur J Anaesthesiol. 1996;13:33-7.

12. Apfel CC, Korttila K, Abdalla M, Kerger H, Turan A, Vedder I. A factorial trial of six interventions for the prevention of postoperative nausea and vomiting. $\mathrm{N}$ Engl J Med. 2004;350(24):2441-51.

13. Pollard BJ, Elliott RA, Moore EW. Anaesthetic agents in adult day case surgery. Eur $\mathrm{J}$ Anaesthesiol. 2003;20:1-9.

14. Sneyd JR, Carr A, Byrom WD, Bilski AJ. A metaanalysis of nausea and vomiting following maintenance of anaesthesia with propofol or inhalational agents. Eur J Anaesthesiol. 1998;15:43345.

15. Wang JJ, Ho ST, Tzeng JI, Tang CS. The effect of timing of dexamethasone administration on its efficacy as a prophylactic antiemetic for postoperative nausea and vomiting. Anesth Analg. 2000;91:136-9.

16. Eberhart LH, Folz BJ, Wulf H, Geldner G. Intravenous anaesthesia provides optimal surgical conditions during microscopic and endoscopic sinus surgery. Laryngoscope. 2003;113(8):1369-73.

17. Tirelli G, Bigarini S, Russolo M, Lucangelo U, Gullo A. Total intravenous anaesthesia in endoscopic sinusnasal surgery. Acta Otorhinolaryngol Ital. 2004;24(3):137-44.

18. Wormald PJ, van Renen G, Perks J, Jones JA, Langton- Hewer CD. The effect of the total intravenous anaesthesia compared with inhalational anaesthesia on the surgical field during endoscopic sinus surgery. Am J Rhinol. 2005;19(5):514-20.

19. Ankichetty SP, Ponniah M, Cherian V, Thomas S, Kumar K, Jeslin L, et al. Comparison of total intravenous anaesthesia using propofol and inhalational anaesthesia using isoflurane for controlled hypotension in functional endoscopic sinus surgery. $\mathbf{J}$ Anaesthesiol Clin Pharmacol. 2011;27(3):328-32.

20. Van Der Stelt M, Di Marzo, V. Cannabinoid receptors and their role in neuroprotection. Neuromol Med. 2005; 7:37-50. 
21. Wu J, Yao S, Wu Z. A comparison of anaesthetic regimens using etomidate and propofol in patients undergoing first-trimester abortions: double-blind, randomized clinical trial of safety and efficacy. Contracep. 2013;87:55-62.
Cite this article as: Gomathi G, Yadav G, Pandey BL. Drug utilization review of general anaesthetic agents in a tertiary care hospital. Int J Basic Clin Pharmacol 2018;7:439-45. 